\title{
Efektivitas stretching, passive activity dan VO2 max dalam mencegah terjadinya delayed onset muscle soreness
}

\author{
Andika Triansyah*, Mimi Haetami \\ Program Studi Pendidikan Jasmani, Fakultas Keguruan dan Ilmu Pendidikan, Universitas \\ Tanjungpura, Jalan Prof. Dr. Hadari Nawawi Pontianak 78124, Indonesia. \\ * Corresponding Author. Email: andika.triansyah@ fkip.untan.ac.id
}

Received: 8 January 2020; Revised: 10 May 2020; Accepted: 15 May 2020

\begin{abstract}
Abstrak: Tujuan dalam penelitian ini adalah: (1) untuk mengetahui apakah ada perbedaan efektivitas Active Isolated Stretching dan Passive Activity dalam mencegah terjadinya Delayed Onset Muscle Soreness setelah olahraga intensitas tinggi; (2) Untuk mengetahui apakah ada perbedaan efektivitas antara VO2Max tinggi dan VO2Max rendah dalam mencegah terjadinya Delayed Onset Muscle Soreness setelah olahraga intensitas tinggi; (3) Untuk mengetahui apakah ada interaksi antara Active Isolated Stretching dan Passive Activity dengan VO2Max dalam mencegah terjadinya Delayed Onset Muscle Soreness setelah olahraga intensitas tinggi. Metode yang digunakan dalam penelitian ini adalah eksperimen. Bentuk penelitian menggunakan rancangan faktorial $2 \times 2$. Teknik pengambilan sampel yang digunakan dalam penelitian ini menggunakan rumus dari Issac \& Michael, sehingga didapat sampel sebanyak 40 orang. Berdasarkan hasil penelitian, dapat disimpulkan bahwa: (1) tidak ada perbedaan efektivitas Active Isolated Stretching dan Passive Activity dalam mencegah terjadinya Delayed Onset Muscle Soreness setelah olahraga intensitas tinggi. (2) Tidak ada perbedaan efektivitas antara VO2Max tinggi dan VO2Max rendah dalam mencegah terjadinya Delayed Onset Muscle Soreness setelah olahraga intensitas tinggi. (3) Tidak ada interaksi antara Active Isolated Stretching, Passive Activity dengan VO2Max dalam mencegah terjadinya Delayed Onset Muscle Soreness setelah olahraga intensitas tinggi.
\end{abstract}

Kata Kunci: Active Isolated Stretching, Passive Activity, Delayed Onset Muscle Soreness

\section{Effectiveness stretching, passive activity and $\mathrm{VO} 2$ max prevent the delayed onset muscle soreness}

\begin{abstract}
The objectives of this study are: (1) To determine whether there are differences in the effectiveness of Active Isolated Stretching and Passive Activity in preventing the delayed onset of muscle soreness after high-intensity exercise; (2) To find out whether there is a difference in effectiveness between high VO2Max and low VO2Max in preventing the delayed onset of muscle soreness after high-intensity exercise; (3) To determine whether there is an interaction between Active Isolated Stretching and Passive Activity with VO2Max in preventing the delayed onset of muscle soreness after high-intensity exercise. The method used in this research is an experiment. The research uses $2 \times 2$ factorial design. Based on the results of research and discussion that the authors do in this study, it can be concluded that: (1) there was no difference in the effectiveness of Active Isolated Stretching and Passive Activity in preventing Delayed Onset Muscle Soreness after high-intensity exercise. (2) There was no difference in effectiveness between high VO2Max and low VO2Max in preventing Delayed Onset Muscle Soreness after high-intensity exercise. (3) There was no interaction between Active Isolated Stretching, Passive Activity with VO2Max in preventing Delayed Onset Muscle Soreness after high-intensity exercise.
\end{abstract}

Keywords: Active Isolated Stretching, Passive Activity, Delayed Onset Muscle Soreness

How to Cite: Triansyah, A., \& Haetami, M. (2020). Efektivitas stretching, passive activity dan VO2max dalam mencegah terjadinya delayed onset muscle soreness. Jurnal Keolahragaan, 8(1), 88-97. doi:https://doi.org/10.21831/jk.v8i1.29487

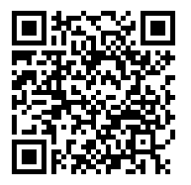

\section{PENDAHULUAN}

Manfaat olahraga bagi kesehatan manusia jelas sangat banyak dan bisa dirasakan oleh setiap orang, tidak bisa dihindari bahwa olahraga menjadi salah satu gaya hidup yang dilakukan setiap orang 
untuk membuat tubuhnya tetap sehat dan bugar. Sebagai sebuah kegiatan untuk mendapatkan kebugaran jasmani dan kesehatan, olahraga atau aktivitas fisik harus dilakukan secara rutin. Fox (Suharjana, 2013) menyatakan aktivitas jasmani atau olahraga akan berpengaruh terhadap peningkatan fungsi organ tubuh seperti otot, syaraf, jantung, pembuluh darah, alat-alat pernafasan, maupun biokimia tubuh. Artinya dengan berolahraga seseorang akan mendapatkan manfaat kesehatan dari aktivitas tersebut, selain itu kemampuan kerja otot juga akan meningkat. Hal tersebut disebabkan oleh perubahan fisiologis yang terjadi pada system neuromuscular. Sasaran utama dari olahraga atau aktivitas fisik adalah untuk meningkatkan kualitas kebugaran energi (energy fitness) dan kebugaran otot (muscular fitness) (Adam, 2018; Sukadiyanto \& Muluk, 2011).

Dampak positif olahraga bagi kesehatan dan kebugaran tubuh sudah tidak terbantahkan lagi, namun disisi lain efek yang dapat ditimbulkan dari olahraga dapat menimbulkan kelelahan. Studi yang dilakukan, mengungkapkan akibat dari olahraga berlebihan, dikutip dari Dewi (2015) studi yang dilakukan oleh University of Utah di Salt Lake City yang telah mengidentifikasi reaksi biokimia yang menyebabkan rasa sakit pada otot dan rasa lelah saat berolahraga. Rasa sakit pada otot yang berkelanjutan adalah salah satu tanda bahwa olahraga yang dilakukan melebihi dari yang seharusnya. Sendi, tulang, dan anggota tubuh kemungkinan akan mulai terasa sakit ketika ada otot-otot yang digunakan secara berlebihan.

Keluhan sakit di otot atau rasa nyeri yang timbul akibat berolahraga dikenal dengan istilah Delayed Onset Muscle Soreness (DOMS). Akibat dari DOMS adalah rasa sakit yang muncul beberapa saat (tertunda) setelah melakukan olahraga. Rasa sakit yang ditandai dengan nyeri akibat dari DOMS akan muncul pada saat akan beraktivitas namun jika sedang beristirahat rasa nyeri tersebut tidak terasa. Semua orang dapat mengalami DOMS, baik itu pemula atau bahkan atlet profesional dapat merasakan nyeri otot setelah latihan. Gejala-gejala akan sering muncul dalam 24 jam setelah latihan dan biasanya menghilang setelah 3-4 hari (Hilbert et al., 2003; Wardana et al., 2018)

Perasaan nyeri yang timbul setelah berolahraga tersebut dapat mengganggu aktifitas sehari-hari, tubuh tidak dapat melakukan gerakan secara bebas karena adanya rasa nyeri di otot, ini dapat menjadi permasalahan terhadap aktifitas yang akan dilakukan, bagi pekerja tentu hal ini dapat mengganggu produktifitas kerja, bagi pelajar atau mahasiswa dapat menimbulkan perasaan malas dengan terbatasnya gerak yang dirasakan, bahkan lebih jauh dapat mengakibatkan muncul presepsi negatif tentang olahraga sehingga menyebabkan orang tidak mau untuk melakukan olahraga dengan intensitas tinggi.

Pada saat berolahraga sering ditemui orang yang mengabaikan tahapan pemanasan dan pendinginan dalam rangkaian olahraga ataupun melakukannya dengan asal-asalan, hal tersebut dapat disebabkan karena belum diketahui pentingnya pemanasan dan pendinginan dalam olahraga atau memang sengaja mengabaikan tahapan tersebut belum diketahui secara pasti. Selain itu juga persepsi setiap orang dapat mengalami DOMS baik orang yang tidak terlatih maupun atlet professional sekalipun membantu memperlemah manfaat dari tahapan pemanasan maupun pendinginan.

DOMS adalah suatu fenomena yang sering ditemui dan terdokumentasi dengan baik, sering terjadi sebagai akibat dari latihan eksentrik yang tidak lazim atau intensitas tinggi (Connolly et al., 2003). DOMS sering dialami oleh semua individu yang melakukan aktivitas fisik tanpa melihat tingkat kebugarannya dan ini adalah respon fisiologis normal untuk meningkatkan penggunaan tenaga dan sebagai pengenalan terhadap aktivitas fisik yang tidak dikenal sebelumnya.

Menurut Szymanski (2001), DOMS adalah nyeri yang dirasakan seseorang dalam waktu 24-72 jam setelah melakukan aktivitas olahraga. DOMS menimbulkan kekakuan, bengkak, penurunan kekuatan dan nyeri pada otot. DOMS disadari dengan adanya rasa nyeri yang didapati 12-24 jam setelah olahraga dan memuncak dalam waktu 24-48 jam setelah olahraga. DOMS adalah sensasi ketidak nyamanan atau nyeri pada otot-otot yang terjadi setelah melakukan latihan yang tidak biasa dilakukan atau dengan intensitas tinggi. Proses terjadinya DOMS dapat dihubungkan dengan pembentukan asam laktat dalam otot pasca olahraga yang intens namun sekarang terbukti bahwa ternyata asumsi tersebut tidak berhubungan langsung dengan kejadian DOMS. DOMS sering ditimbulkan terutama oleh gerakan eksentrik. Berbagai jenis olahraga menyebabkan deformitas sel membran otot sehingga akan diawali terjadinya respon inflamasi yang menyebabkan pembentukan produk-produk sampah metabolik, untuk berperan sebagai stimulus kimiawi kepada ujung saraf. Kontraksi eksentrik terjadi saat otot yang aktif sedang memanjang hal tersebut dapat berhubungan adanya peningkatan yang terlambat pada tingkat serum dari enzim spesifik otot seperti creatin kinase (CK) sehingga memicu kerusakan serabut otot. Gejala-gejala yang menyertai meliputi pemendekan otot, peningkatan kekakuan terhadap gerak pasif, 
bengkak, penurunan kekuatan dan daya ledak otot, sakit lokal, dan rasa posisi sendi/proprioception yang terganggu (Szymanski, 2001).

Karena itu olahraga yang menyebabkan kerusakan otot/exerciseinduced muscle damage, dapat dihubungkan dengan adanya inflamasi aseptic, yang didukung beberapa bukti bahwa permukaan otot yang mengalami nyeri dan bengkak. Nyeri yang terjadi merupakan rangsangan yang berasal dari jaringan otot dan arteri, kapiler darah, serta tendon yang mengalami cedera. Inflamasi merupakan proses awal penyembuhan DOMS yang terjadi segera setelah beberapa menit setelah perdarahan. Indikator inflamasi dapat dilihat dengan terjainya peningkatan konsentrasi CK antara 1-7 hari setelah latihan. Selain CK indikator lain yang dapat menjadi penanda inflamasi adalah jumlah leukosit, neutrofil, monosit dan basofil yang mengalami perubahan ketika cedera terjadi. CK (creatinin kinase) merupakan salah satu indikator terjadinya permeabilitas enzim pada membran yang terjadi pada otot skeletal dan otot jantung (Connolly et al., 2003).

Dalam aktifitas fisik terdapat dua jenis kontraksi otot, bergantung pada perubahan panjang otot selama berkontraksi, yaitu kontraksi isometrik dan kontraksi isotonik. Kontraksi isometrik adalah kontraksi otot yang tidak disertai dengan perubahan panjang otot. Contoh kontraksi isometrik adalah kontraksi otot pada saat mendorong tembok. Kontraksi isotonik adalah kontraksi otot yang disertai dengan perubahan panjang otot dengan tegangan tetap/konstan (Lhaksana, 2011; Siregar, 2016; Suharjana, 2013). Contoh dari kontraksi isotonik adalah kontraksi otot biceps pada saat mengangkat beban berat misalnya barbel. Kontraksi isotonik dibagi menjadi dua yaitu kontraksi konsentrik (otot memendek) dan kontraksi eksentrik (otot memanjang).

$D O M S$ sering ditimbulkan terutama oleh latihan eksentrik seperti lari menuruni bukit atau downhill running, plyometrics, dan latihan dengan tahanan. Pada dasarnya setiap gerakan yang tidak biasa dilakukan akan menimbulkan nyeri otot, khususnya gerakan yang membuat otot berkontraksi memanjang. Contoh kegiatan yang menyebabkan kontraksi otot yang seperti ini antara lain naik-turun tangga, jogging, menurunkan berat badan (seperti pada latihan bicep curl, squat, dan push-up. Berbagai latihan ini menyebabkan kerusakan pada sel membran otot sehingga akan memulai terjadinya respon inflamasi, menyebabkan pembentukan produk-produk sampah metabolik, yang berperan sebagai stimulus kimiawi kepada ujung saraf atau nerve endings. Latihan beban merupakan olahraga dengan intensitas yang tinggi, sehingga masalah utama yang sering dialami oleh para olahragawan adalah kelelahan atau ketidakmampuan untuk memulihkan rasa lelah dari satu latihan ke latihan berikutnya. Kelelahan otot adalah penurunan performa otot akibat aktivitas fisik. Hal ini menyebabkan kapasitas kekuatan maksimal otot berkurang (Perez \& Jakeman, 2010). Selain mengurangi kapasitas kekuatan maksimal, akumulasi dari sisa metabolit akibat dari aktivitas fisik menyebabkan sensasi terbakar dan nyeri pada otot yang akan semakin bertambah seiring waktu dan mencapai puncaknya pada 1-2 hari setelah latihan (Sirait et al., 2015).

DOMS selalu dikaitkan dengan keadaan yang tidak biasa, kerja otot yang berlebihan dan kontraksi eksentrik dapat memicu terjadinya DOMS. Kontraksi otot eksentrik dapat dilihat dari adanya perpanjangan otot selama otot berkontraksi. Muscle soreness terjadi ketika muscle fiber mengalami robekan, dan otot beradaptasi untuk menjaga kekuatannya. Muscle strain terjadi karena akibat dari overtraining yang tejadi pada sebagian besar muscle fiber yang berpengaruh terhadap derajat gerak dan tendon (Connolly et al., 2003).

Tingkat kerusakan dan nyeri dapat disebabkan beberapa faktor misalnya pada tingkat profesional dapat disebabkan karena dosis latihan dan intensitas dari latihan yang diberikan. Bila pada seseorang yang bukan atlet kerusakan dapat disebabkan karena aktifitas otot melebihi dari kemampuan dalam melakukan aktifitas dan gerakan yang salah. Faktor yang lain adalah stiffness, kecepatan kontraksi, lelah otot, dan sudut pada saat akan melakukan gerakan. Dengan memperhatikan teori dan ilmu dasar pada mekanisme injury, penanganan untuk DOMS akan bisa meminimalkan kerusakan pada jaringan dan menghindarkan dari latihan otot yang berlebihan. DOMS dapat diklasifikasikan sebagai cedera pada otot tipe I dan dapat diketahui dengan adanya nyeri tekan dan spasme pada saat dilakukan palpasi dan gerakan. Nyeri tekan dapat terlokalisasi pada bagian distal otot dan dapat bertambah nyeri dalam waktu 24-48 jam setelah melakukan latihan. Rasa nyeri tersebut dapat menggambarkan tingginya receptor pada jaringan lunak dan pada tendon otot (Cheung et al., 2003). Melakukan latihan yang tidak terprogram dengan latihan eksentrik dapat menyebabkan terjadinya cedera karena pemberian latihan yang berulang-ulang. Jika latihan yang dilakukan secara overload maka akan menimbulkan cedera pada otot dan akan menyebabkan terjadinya kerusakan otot karena efek latihan yang berat. Latihan yang tidak 
dikontrol dengan baik tersebut dapat menyebabkan timbulnya kerusakan otot, peradangan, dan nyeri serta menurunnya lingkup gerak sendi. Adanya gangguan pada komponen kontraktil otot tertama pada Z-line pada latihan eksentrik. Karasteristik lesi mikroskopik meluas dan akan terjadi kerusakan total myofibril pada Z-line, dan akan meluas pada kerusakan sarkomer. Ini merupakan salah satu penyebab ketegangan atau nyeri pada semua area otot yang akan mengurangi keterlibatan motor unit pada saat kontraksi eksentrik. Nociceptor pada jaringan ikat pada daerah arteri, kapiler dan struktur jaringan otot dan tendon akan terjadi atau timbul sensasi nyeri (Cheung et al., 2003). Berdasarkan penjelasan di atas, dalam mencegah terjadinya DOMS perlu dilakukan penelitian komparasi untuk meyakinkan manfaat tahapan pemanasan/pendinginan dan kemampuan kapasitas aerobik seseorang. Sehingga peneliti menetapkan judul efektifitas Active Isolated Stretching, Passive Activity dan VO2Max dalam mencegah terjadinya Delayed Onset Muscle Soreness setelah olahraga intensitas tinggi.

\section{METODE}

Metode yang digunakan dalam penelitian ini adalah eksperimen. Bentuk penelitian menggunakan rancangan faktorial $2 \times 2$ yang melibatkan 2 variabel yaitu: (1) Variabel bebas/independent berupa efektivitas Active Isolated Stretching (AIS) dan Passive Activity serta variabel moderator berupa kemampuan VO2Max tinggi dan VO2Max rendah. (2) Variabel terikat/dependent berupa mencegah terjadinya Delayed Onset Muscle Soreness setelah olahraga intensitas tinggi. Eksperimen faktorial adalah eksperimen yang hampir semua faktor dikombinasikan atau disilangkan dengan tiap faktor lainnya yang ada dalam eksperimen. Sehingga desain penelitian faktorial 2 x 2 dalam penelitian ini dapat dilihat pada Tabel 1:

Tabel 1. Desain Penelitian Faktorial 2 x 2

\begin{tabular}{cccc}
\hline & Treatment A1 & AIS (A1) & Passive Activity (A2) \\
$\mathrm{O}_{2}$ Max A2 & & A1B1 & A2B1 \\
& VO2Max tinggi (B1) & A1B2 & A2B2 \\
\hline VO2Max rendah (B2) &
\end{tabular}

Keterangan:

A1B1 = Treatment AIS dengan kemampuan VO2Max tinggi.

$\mathrm{A} 1 \mathrm{~B} 2=$ Treatment AIS dengan kemampuan VO2Max rendah.

$\mathrm{A} 2 \mathrm{~B} 1$ = Passive Activity dengan kemampuan VO2Max tinggi.

A2B2 = Passive Activity dengan kemampuan VO2Max rendah.

Penelitian ini dilakukan di lapangan Kampus 3 Ilmu Keolahragaan, Fakultas Keguruan dan Ilmu Pendidikan Universitas Tanjungpura (FKIP Untan). Jumlah sampel dalam penelitian ini adalah sebanyak 40 orang mahasiswa prodi pendidikan jasmani FKIP Untan angkatan 2017. Dari 40 orang sampel selanjutnya ditentukan 20 orang dengan VO2Max tinggi dan 20 orang dengan VO2Max rendah, Kemudian dari 40 orang juga dibagi menjadi 4 kelompok/sel (sel pada faktorial 2x2) sehingga dalam setiap kelompok/sel di isi oleh 10 orang.

Teknik pengumpulan data dalam penelitian ini dilakukan dengan teknik tes dan pengukuran. Teknik tes digunakan untuk mengukur VO2Max, Untuk menentukan kemampuan VO2Max digunakan instrumen multi stage fitness test (bleep test) dengan satuan $\mathrm{ml} / \mathrm{kg} /$ menit. sedangkan teknik pengukuran digunakan untuk mengukur Delayed Onset Muscle Soreness (DOMS). Data pengukuran DOMS yang diambil ialah data sesudah perlakuan yang diberikan 24 jam dan 48 jam sesudanya. Gejala DOMS yang diukur adalah nyeri gerak dan penambahan lingkar otot paha (bengkak). Setelah 24 jam pasca olahraga intensitas tinggi, nyeri diukur dengan Visual Analogue Scale (VAS) (Lau et al., 2013).

Analisis data dilakukan dengan teknik analysis of variance (anova) dengan bantuan SPSS 20.00 for windows. Jika nilai signifikansi (2-tailed) lebih kecil dari 0.05, maka Ha diterima, artinya (1) Ada perbedaan efektivitas Active Isolated Stretching dan Passive Activity dalam mencegah terjadinya Delayed Onset Muscle Soreness setelah olahraga intensitas tinggi; (2) Ada perbedaan efektivitas antara VO2Max tinggi dan VO2Max rendah dalam mencegah terjadinya Delayed Onset Muscle Soreness setelah olahraga intensitas tinggi; (3) Ada interaksi antara Active Isolated Stretching dan Passive Activity dengan VO2Max dalam mencegah terjadinya Delayed Onset Muscle Soreness setelah olahraga intensitas tinggi. 
Jurnal Keolahragaan 8 (1), 2020 - 92

Andika Triansyah, Mimi Haetami

\section{HASIL DAN PEMBAHASAN}

Pada penelitian ini hasil analisis data meliputi karakteristik sampel, distribusi nilai VO2Max, distribusi nilai nyeri 24 jam setelah latihan berdasarkan VO2Max, distribusi perubahan lingkar paha sebelum dan 24 jam sesudah latihan serta hasil uji hipotesis. Tabel 2 merupakan hasil penelitian yang meliputi karakteristik sampel:

Tabel 2. Karakteristik Sampel

\begin{tabular}{lcc}
\hline Karakteristik & Jumlah & Presentasi \\
\hline Jenis Kelamin & & \\
Laki-laki & 31 & $77.5 \%$ \\
Perempuan & 9 & $22.5 \%$ \\
Stretching & & \\
$\quad$ AIS & 20 & $50 \%$ \\
$\quad$ Pasif & 20 & $50 \%$ \\
VO2Max & & \\
$\quad$ Tinggi & 20 & $50 \%$ \\
$\quad$ Rendah & 20 & $50 \%$ \\
\hline
\end{tabular}

Berdasarkan Tabel 2, dapat dilihat karakteristik sampel penelitian berjenis kelamin laki-laki dengan jumlah 32 orang $(80 \%)$, sedangkan jumlah subjek penelitian berjenis kelamin perempuan berjumlah 8 orang (20\%). Selain itu pada tabel 2 nilai VO2Max dari 40 responden menunjukkan 20 orang (50\%) memiliki kategori VO2Max Tinggi dan 20 orang (50\%) menunjukan memiliki VO2Max Rendah.

\section{Distribusi AIS dan Pasif Activity terhadap DOMS}

Selanjutnya dipaparkan data distribusi AIS dan Pasif activity terhadap DOMS setelah olahraga intensitas tinggi.

Tabel 3. Distribusi AIS dan Pasif activity Terhadap DOMS

\begin{tabular}{lll}
\hline \multicolumn{1}{c}{ Siklus } & \multicolumn{1}{c}{ AIS } & \multicolumn{1}{c}{ Passive Activity } \\
\cline { 2 - 3 } & \multicolumn{1}{c}{ Pentivitas } \\
\hline 24 Jam setelah latihan & $0(0 \%)$ & $1(5 \%)$ \\
Tidak nyeri & $12(60 \%)$ & $13(65 \%)$ \\
Nyeri ringan & $4(20 \%)$ & $6(30 \%)$ \\
Nyeri sedang & $4(20 \%)$ & $0(0 \%)$ \\
Nyeri berat & $0(0 \%)$ & $0(0 \%)$ \\
Nyeri sangat berat & $20(100 \%)$ & $20(100 \%)$ \\
Total & $3(15 \%)$ & $3(15 \%)$ \\
48 Jam setelah latihan & $13(65 \%)$ & $14(70 \%)$ \\
Tidak nyeri & $2(10 \%)$ & $2(10 \%)$ \\
Nyeri ringan & $2(10 \%)$ & $1(5 \%)$ \\
Nyeri sedang & $0(0 \%)$ & $0(0 \%)$ \\
Nyeri berat & $20(100 \%)$ & $20(100 \%)$ \\
Nyeri sangat berat & & \\
\end{tabular}

Tabel 3 menunjukkan bahwa terdapat lima tingkatan nyeri yaitu tidak nyeri, sedikit nyeri, lebih nyeri, sangat nyeri dan nyeri sangat berat. Data dikelompokkan kedalam dua jenis aktivitas sebelum dan sesudah latihan yaitu Active Isolated Stretching dan Passive Activity dan dibagi menjadi dua waktu yaitu efek 24 jam setelah latihan dan 48 jam setelah latihan. Pada sampel yang melakukan Active Isolated Stretching 24 jam setelah latihan, sebanyak 13 orang $(65 \%)$ mengalami nyeri ringan. 3 orang $(15 \%)$ yang mengalami nyeri sedang, dan 4 orang $(20 \%)$ mengalami nyeri berat. Sedangkan dari data rasa nyeri setelah 48 jam dengan sampel yang sama didapatkan hasil 2 orang (10\%) tidak nyeri, 13 orang $(65 \%)$ nyeri ringan, 3 orang (15\%) mengalami nyeri sedang dan 2 orang (10\%) mengalami nyeri berat. Hasil berbeda didapatkan pada responden yang melakukan Passive Activity. Dalam waktu 24 jam setelah latihan 1 orang (5\%) tidak merasakan nyeri. 13 orang (65\%) mengalami nyeri ringan dan 4 orang $(20 \%)$ mengalami nyeri sedang, 2 orang (10) mengalami nyeri berat. Sedangkan pada 48 jam setelah latihan, sampel yang melakukan Passive Activity 3 orang (15\%) tidak merasakan nyeri, 12 orang (60\%) mengalami nyeri ringan, 4 orang (20\%) mengalami nyeri sedang dan 1 orang (5\%) mengalami nyeri berat. 
Sejauh ini belum banyak diketahuinya penelitian terkait pengaruh stretching dan VO2Max terhadap DOMS secara langsung. Namun terdapat beberapa penelitian yang menghubungkan antara fleksbilitas dengan resiko terjadinya muscle strain dan muscle injury. DOMS ini merupakan mikroruptur yang terjadi pada struktur otot, hampir sama dengan muscle strain. Sehingga penelitian tersebut dianggap bisa dijadikan acuan dalam pembahasan. (Witvrouw et al., 2003) di Ghent University Belgium telah melakukan penelitan tentang fleksibilitas otot sebagai faktor resiko peningkatan cedera otot pada pemain sepak bola profesional Belgia. Hasil penelitian tersebut menunjukkan bahwa fleksibilitas otot hamstring yang kurang dari $90^{\circ}$ dapat dianggap sebagai otot yang kaku karena pemain ini memiliki resiko lebih tinggi untuk cedera. Oleh karena itu berdasarkan hasil penelitian tersebut, pemain sepak bola dengan fleksibilitas otot hamstring kurang dari $90^{\circ}$ harus didorong untuk peregangan secara intensif untuk mengurangi resiko terjadinya cedera otot. Dari sebaanyak 67 responden yang mengalami cedera, sebanyak 46,2\% mengalami cedera hamstring. Pada pemain tersebut ditemukan memiiliki tingkat fleksibilitas secara signifikan lebih rendah dibandingkan dengan kelompok yang tidak mengalami cedera. Temuan tersebut sejalan dengan pendapat para pakar kesehatan olahraga di Belgia bahwa fleksibilitas otot memainkan peranan penting dalam upaya pencegahan muscle strain dan muscle injury lainnya.

\section{Distribusi VO2Max terhadap DOMS}

Selanjutnya akan disajikan data VO2Max terhadap DOMS hasil yang didapat disajikan pada Tabel 4.

Tabel 4. Distribusi VO2 Max terhadap DOMS

\begin{tabular}{lll}
\hline \multirow{2}{*}{ Siklus } & \multicolumn{1}{c}{ VO2Max } \\
\cline { 2 - 3 } & \multicolumn{1}{c}{ Tinggi } & Rendah \\
\hline 24 Jam setelah latihan & & \\
Tidak nyeri & $1(5 \%)$ & $0(0 \%)$ \\
Nyeri ringan & $12(60 \%)$ & $13(65 \%)$ \\
Nyeri sedang & $5(25 \%)$ & $5(25 \%)$ \\
Nyeri berat & $2(10 \%)$ & $2(10 \%)$ \\
Nyeri sangat berat & $0(0 \%)$ & $0(0 \%)$ \\
Total & $20(100 \%)$ & $20(100 \%)$ \\
48 Jam setelah latihan & & $2(10 \%)$ \\
Tidak nyeri & $4(20 \%)$ & $15(75 \%)$ \\
Nyeri ringan & $12(60 \%)$ & $1(5 \%)$ \\
Nyeri sedang & $3(15 \%)$ & $2(10 \%)$ \\
Nyeri berat & $1(5 \%)$ & $0(0 \%)$ \\
Nyeri sangat berat & $0(0 \%)$ & $20(100 \%)$ \\
\end{tabular}

Dari data pada Tabel 4 menunjukkan bahwa terdapat lima tingkatan nyeri yaitu tidak nyeri, sedikit nyeri, lebih nyeri, sangat nyeri dan nyeri sangat berat. Data dikelompokkan ke dalam dua jenis yaitu kemampuan VO2Max tinggi dan VO2Max rendah serta dibagi menjadi dua waktu yaitu efek 24 jam setelah latihan dan 48 jam setelah latihan. Pada sampel yang memiliki VO2Max tinggi 24 jam setelah latihan, sebanyak 1 orang (5\%) merasakan tidak nyeri, 12 orang (60\%) mengalami nyeri ringan, 5 orang (25\%) yang mengalami nyeri sedang, dan 2 orang (10\%) mengalami nyeri berat. Sedangkan dari data rasa nyeri setelah 48 jam dengan kemampuan sampel yang sama didapatkan hasil, 13 orang (65\%) nyeri ringan, 5 orang (25\%) mengalami nyeri sedang dan 2 orang (10\%) mengalami nyeri berat.

Hasil berbeda didapatkan pada sampel yang memiliki kemampauan VO2Max rendah. Dalam waktu 24 jam setelah latihan 4 orang $(20 \%)$ tidak merasakan nyeri. 12 orang $(60 \%)$ mengalami nyeri ringan dan 3 orang (15\%) mengalami nyeri sedang, 1 orang (5\%) mengalami nyeri berat. Sedangkan pada 48 jam setelah latihan, sampel yang memiliki karakteristik yang sama 2 orang (10\%) tidak merasakan nyeri, 15 orang (75\%) mengalami nyeri ringan, 1 orang $(5 \%)$ mengalami nyeri sedang dan 2 orang $(10 \%)$ mengalami nyeri berat. Hasil dari penelitian ini juga sejalan dengan pendapat yang dikemukakan oleh (Szymanski, 2001) Delayed Onset Muscle Soreness (DOMS) mempunyai tipikal gangguan yang menyebabkan kekakuan, bengkak, penurunan kekuatan dan nyeri pada otot. DOMS adalah gangguan berupa pegal otot yang terjadi akibat latihan yang tidak lazim yang menyebabkan kerusakan pada membran sel otot sehingga meyebabkan terjadinya respon inflamasi. DOMS sering dialami oleh semua individu yang melakukan aktivitas fisik tanpa melihat tingkat kebugarannya dan ini adalah respon 
fisiologis normal untuk meningkatkan penggunaan tenaga dan sebagai pengenalan terhadap aktivitas fisik yang tidak dikenal sebelumnya.

Untuk hasil data selanjutnya yaitu penyebaran hasil peneltian lingkar paha antara 24 Jam dan 48 Jam setelah olahraga.

Tabel 5. Distribusi Lingkar Paha Antara 24 Jam dan 48 Jam Setelah Olahraga.

\begin{tabular}{cccc}
\hline \multirow{2}{*}{ Perubahan Lingkar Paha } & \multicolumn{2}{c}{ Jenis Kelamin } & \multirow{2}{*}{ Jumlah } \\
\cline { 2 - 3 } & Laki-laki & Perempuan & $18(45 \%)$ \\
Mengecil & $14(45 \%)$ & 4 orang $(45 \%)$ & $10(25 \%)$ \\
Tetap & $7(23)$ & 3 orang $(33 \%)$ & $12(30 \%)$ \\
Membesar & $10(32 \%)$ & 2 orang $(22 \%)$ & $40(100 \%)$ \\
Total & $31(100 \%$ & $9(100 \%)$ & \\
\hline
\end{tabular}

Pengujian data yang diperoleh setelah perlakuan stretching (AIS), Pasif Activity dan VO2Max terhadap DOMS dilakukan dengan 3 tahapan, pertama memisahkan data antara treatment sampel yang melakukan pemanasan dan pendinginan dengan stretching $(A I S)$ dan sampel yang tidak melakukan aktifitas pemanasan dan pendinginan atau pasif activity.

\section{Pengaruh AIS dan Passive Activity terhadap DOMS}

Rumusan hipotesis pertama yang diajukan adalah terdapat pengaruh yang signifikan Active Isolated Stretching dan Passive Activity dalam mencegah terjadinya Delayed Onset Muscle Soreness setelah olahraga intensitas tinggi. Pada taraf signifikansi 5\% ditentukan kriteria pengambil keputusan $\mathrm{H}_{0}$ ditolak jika nilai signifikansi $P$-value $<0,05$.

Tabel 6. Uji Hipotesis 1

\begin{tabular}{cccc}
\hline Effect & Sig & $\alpha$ & Ket \\
\hline AIS \& Passive Activity terhadap DOMS & 0,64 & 0,05 & $\mathrm{H}_{0}$ diterima \\
\hline
\end{tabular}

Hasil analisis uji anova diketahui nilai signifikansi $P$-value sebesar 0,64 yang berarti 0,64>0,05, sehingga $\mathrm{H}_{0}$ yang berbunyi tidak ada perbedaan efektivitas Active Isolated Stretching dan Passive Activity dalam mencegah terjadinya Delayed Onset Muscle Soreness setelah olahraga intensitas tinggi, diterima. Artinya tidak ada perbedaan efektivitas Active Isolated Stretching dan Passive Activity dalam mencegah terjadinya Delayed Onset Muscle Soreness setelah olahraga intensitas tinggi. Tidak ada perbedaan efektivitas tersebut dapat disebabkan karena DOMS adalah adalah respon fisiologis normal untuk meningkatkan penggunaan tenaga dan sebagai pengenalan terhadap aktivitas fisik yang tidak dikenal sebelumnya/beban berlebih. Oleh karena itu olahraga dengan intensitas tinggi dapat menyebabkan kerusakan otot/exerciseinduced muscle damage yang dapat dihubungkan dengan adanya inflamasi aseptic serta didukung beberapa bukti bahwa permukaan otot yang mengalami nyeri dan bengkak. Nyeri yang terjadi merupakan rangsangan yang berasal dari jaringan otot dan arteri, kapiler darah, serta tendon yang mengalami cedera (Connolly et al., 2003).

Hasil penelitian memang tidak menyatakan ada perbedaan efektivitas Active Isolated Stretching dan Passive Activity dalam mencegah terjadinya Delayed Onset Muscle Soreness setelah olahraga intensitas tinggi namun perlu diperhatikan bahwa fleksibilitas merupakan hal yang penting dalam olahraga. Untuk mendapat derajat fleksibilitas yang baik dapat dilakukan dengan stretching. Peregangan (stretching) merupakan metode latihan yang digunakan untuk meningkatkan fleksibilitas (Sukadiyanto \& Muluk, 2011). Berdasarkan pernyataan tersebut hubungan keduanya sangat erat antara fleksibilitas dan peregangan dimana kelentukan (fleksibilitas) merupakan hasil atau tujuan yang ingin dicapai sedangkan peregangan (stretching) merupakan proses atau cara untuk meningkatkan atau mendapatkan kelentukan (fleksibilitas) itu sendiri. Hasil temuan (Lesmana et al., 2018) sirkulasi darah memiliki peran yang penting dalam proses penyembuhan cedera, termasuk DOMS. Dengan sirkulasi yang baik maka diharapkan nutrisi, oksigen dan zat lainnya yang berguna untuk penyembuhan akan terdistribusi ke jaringan yang mengalami cedera. Salah satu cara agar sikulasi darah tetap berjalan dengan baik adalah dengan melakukan recovery. Recovery aktif dapat membantu proses penyembuhan dengan cara meningkatkan sirkulasi.

Orang yang jarang beraktivitas atau berolahraga akan menyebabkan otot mengalami pemendekan. Pada saat otot memendek, komponen yang ada dalam otot yaitu myofibril (aktin dan myosin), sarkomer serta fascia kehilangan ekstensibilitas serta fleksibilitasnya, dimana filamen-filamen aktin dan myosin yang tumpang tindih bertambah dan karena itu jumlah ikatan silang akan bertambah, jumlah sarkomer 
berkurang serta terbentuknya abnormal cross-link dan adanya taut band pada serabut otot yang pada akhirnya membuat otot memendek. Otot yang memendek akan mempengaruhi kekuatan otot dan fleksibilitas otot. Perbaikan dalam fleksibilitas otot akan dapat mengurangi terjadinya cedera pada otot. Otot yang mengalami pemendekan menyebabkan menurunnya fleksiblitas seseorang (Suharjana, 2013). Keadaan ini akan menyebabkan orang mudah terkena DOMS jika diberikan latihan eksentrik atau olahraga intensitas tinggi, karena otot yang kehilangan ekstensibilitas dan elastisitasnya akan mudah mengalami ketegangan, terlebih saat diberikan latihan eksentrik atau olahraga dengan intensitas yang melebihi kemampuan fisiknya, sehingga akan mudah mengalami cedera.

\section{Pengaruh VO2Max terhadap DOMS}

Selanjutnya tahapan kedua pengujian dilakukan berdasarkan tingkat kemampuan VO2Max sampel yang dibagi menjadi 2 kategori yaitu tinggi dan rendah. Rumusan hipotesis kedua yang diajukan adalah terdapat pengaruh yang signifikan antara VO2Max tinggi dan VO2Max rendah dalam mencegah terjadinya Delayed Onset Muscle Soreness setelah olahraga intensitas tinggi. Pada taraf signifikansi 5 $\%$ ditentukan kriteria pengambil keputusan $\mathrm{H}_{0}$ ditolak jika nilai signifikansi $P$-value $<0,05$.

Tabel 7. Uji Hipotesis 2

\begin{tabular}{cccc}
\hline Effect & Sig & $\alpha$ & Ket \\
\hline VO2Max tinggi \& rendah terhadap DOMS & 0,10 & 0,05 & $\mathrm{H}_{0}$ diterima \\
\hline
\end{tabular}

Hasil analisis uji anova diketahui nilai signifikansi $P$-value sebesar 0,10 yang berarti $0,10>0,05$, sehingga $\mathrm{H}_{0}$ yang berbunyi tidak ada perbedaan efektivitas antara VO2Max tinggi dan VO2Max rendah dalam mencegah terjadinya Delayed Onset Muscle Soreness setelah olahraga intensitas tinggi, diterima. Artinya tidak ada perbedaan efektivitas antara VO2Max tinggi dan VO2Max rendah dalam mencegah terjadinya Delayed Onset Muscle Soreness setelah olahraga intensitas tinggi. Hal ini membuktikan bahwa DOMS dapat dialami oleh semua individu yang melakukan aktivitas fisik tanpa melihat tingkat VO2Max/kebugarannya dan ini adalah respon fisiologis normal akibat dari olahraga intensitas tinggi atau penggunaan beban berlebih saat berolahraha/latihan.

$D O M S$ adalah suatu fenomena yang sering ditemui dan terdokumentasi dengan baik, sering terjadi sebagai akibat dari latihan eksentrik yang tidak lazim atau intensitas tinggi(Connolly et al., 2003). Gejala-gejala yang menyertai meliputi pemendekan otot, peningkatan kekakuan terhadap gerak pasif, bengkak, penurunan kekuatan dan daya ledak otot, sakit lokal, dan rasa posisi sendi/proprioception yang terganggu (Proske \& Morgan, 2001). Gejala-gejala akan sering muncul dalam 24 jam setelah latihan dan biasanya menghilang setelah 3-4 hari (Szymanski, 2001). DOMS adalah sensasi ketidak nyamanan atau nyeri pada otot-otot yang terjadi setelah melakukan latihan yang tidak biasa dilakukan atau dengan intensitas tinggi. Semua alasan ini didukung dengan berbagai hasil penelitian. Bukti yang paling kuat menyatakan robekan mikroskopik pada otot dan kerusakan pada jaringan konektif yang berhubungan dengan otot adalah faktor utama yang terlibat dalam timbulnya DOMS dilaporkan sebagai kejadian yang paling sering terjadi pada peserta lomba lari marathon dan kompetisi angkat besi (Selkar et al., 2009).

\section{Interaksi AIS, Pasif Activity dan VO2Max terhadap DOMS}

Langkah ketiga yang dilakukan pengujian untuk mencari interaksi antara variabel bebas dan moderat terhadap variabel terikat. Variabel bebas yaitu AIS dan Pasif activity, variabel moderat yaitu VO2Max tinggi dan VO2Max rendah, sedangkan variabel terikat yaitu DOMS. Rumusan hipotesis ketiga yang diajukan adalah ada interaksi antara Active Isolated Stretching, Passive Activity dengan VO2Max dalam mencegah terjadinya Delayed Onset Muscle Soreness setelah olahraga intensitas tinggi. Pada taraf signifikansi $5 \%$ ditentukan kriteria pengambil keputusan $\mathrm{H}_{0}$ ditolak jika nilai signifikansi $P$-value < 0,05 .

Tabel 8. Uji Hipotesis 3

\begin{tabular}{cccc}
\hline Effect & Sig & $\alpha$ & Ket \\
\hline Interaksi AIS, Passive Activity \& VO2Max terhadap DOMS & 0,38 & 0,05 & $\mathrm{H}_{0}$ diterima \\
\hline
\end{tabular}

Hasil analisis uji terhadap interaksi diketahui nilai signifikansi $P$-value sebesar 0,38 yang berarti 0,38>0,05, sehingga $\mathrm{H}_{0}$ yang berbunyi tidak ada interaksi antara Active Isolated Stretching, Passive Activity dengan VO2Max dalam mencegah terjadinya Delayed Onset Muscle Soreness setelah olahraga 
intensitas tinggi, ditolak. Artinya tidak ada interaksi antara Active Isolated Stretching, Passive Activity dengan VO2Max dalam mencegah terjadinya Delayed Onset Muscle Soreness setelah olahraga intensitas tinggi. Tidak adanya interaksi tersebut disebabkan karena rangkaian dari penjelas sebelumnya yaitu tidak terdapatnya perbedaan efektivitas Active Isolated Stretching, Passive Activity dengan VO2Max dalam mencegah terjadinya Delayed Onset Muscle Soreness setelah olahraga intensitas tinggi yang sudah tentu berdampak pada tidak adanya interaksi yang terjadi. Meski hasil penelitian menyatakan tidak terdapat interaksi antara Active Isolated Stretching, Passive Activity dengan VO2Max dalam mencegah terjadinya Delayed Onset Muscle Soreness setelah olahraga intensitas tinggi, namun tetap perlu diperhatikan bahwa DOMS selalu dikaitkan dengan keadaan yang tidak biasa, kerja otot yang berlebihan dan kontraksi eksentrik dapat memicu terjadinya DOMS. Kontraksi otot eksentrik dapat dilihat dari adanya perpanjangan otot selama otot berkontraksi. Muscle soreness terjadi ketika muscle fiber mengalami robekan, dan otot beradaptasi untuk menjaga kekuatannya. Muscle strain terjadi karena akibat karena overtraining yang tejadi pada sebagian besar muscle fiber yang berpengaruh terhadap derajat gerak dan tendon (Connolly et al., 2003). Tingkat kerusakan dan nyeri dapat disebabkan beberapa faktor misalnya pada tingkat profesional dapat disebabkan karena dosis latihan dan intensitas dari latihan yang diberikan. Bila pada seseorang yang bukan atlet kerusakan dapat disebabkan karena aktifitas otot melebihi dari kemampuan dalam melakukan aktifitas dan gerakan yang salah. Faktor yang lain adalah stiffness, kecepatan kontraksi, lelah otot, dan sudut pada saat akan melakukan gerakan. Dengan memperhatikan teori dan ilmu dasar pada mekanisme injury, penanganan untuk DOMS akan bisa meminimalkan kerusakan pada jaringan dan menghindarkan dari latihan otot yang berlebihan. $D O M S$ dapat diklasifikasikan sebagai cedera pada otot tipe I dan dapat diketahui dengan adanya nyeri tekan dan spasme pada saat dilakukan palpasi dan gerakan. Nyeri tekan dapat terlokalisasi pada bagian distal otot dan dapat bertambah nyeri dalam waktu 24-48 jam setelah melakukan latihan. Rasa nyeri tersebut dapat menggambarkan tingginya receptor pada jaringan lunak dan pada tendon otot (Cheung et al., 2003). DOMS dapat terjadi karena nyeri otot yang tertunda yang disebabkan karena kerusakan jaringan otot. Melakukan olahraga intensitas tinggi/latihan eksentrik dengan overload maka dapat berpotensi menimbulkan cedera pada otot, peradangan, dan nyeri serta menurunnya lingkup gerak sendi karena efek dari latihan yang berat tersebut. Adanya gangguan pada komponen kontraktil otot tertama pada Z-line pada latihan eksentrik. Karasteristik lesi mikroskopik meluas dan akan terjadi kerusakan total myofibril pada Z-line, dan akan meluas pada kerusakan sarkomer. Ini merupakan salah satu penyebab ketegangan atau nyeri pada semua area otot yang akan mengurangi keterlibatan motor unit pada saat kontraksi eksentrik. Nociceptor pada jaringan ikat pada daerah arteri, kapiler dan struktur jaringan otot dan tendon akan terjadi atau timbul sensasi nyeri (Cheung et al., 2003).

\section{SIMPULAN}

Berdasarkan hasil penelitian yang dilakukan, dapat disimpulkan bahwa: (1) tidak ada perbedaan efektivitas Active Isolated Stretching dan Passive Activity dalam mencegah terjadinya Delayed Onset Muscle Soreness setelah olahraga intensitas tinggi; (2) tidak ada perbedaan efektivitas antara VO2Max tinggi dan VO2Max rendah dalam mencegah terjadinya Delayed Onset Muscle Soreness setelah olahraga intensitas tinggi; (3) tidak ada interaksi antara Active Isolated Stretching, Passive Activity dengan VO2Max dalam mencegah terjadinya Delayed Onset Muscle Soreness setelah olahraga intensitas tinggi.

\section{DAFTAR PUSTAKA}

Adam, Q. H. (2018). Pemberdayaan masyarakat di Kelurahan Wonosari melalui olahraga. Dimas: Jurnal Pemikiran Agama Untuk Pemberdayaan, 18(1), 111. https://doi.org/10.21580/dms.2018.181.2916

Cheung, K., Hume, P. A., \& Maxwell, L. (2003). Delayed onset muscle soreness. Sports Medicine, 33(2), 145-164. https://doi.org/10.2165/00007256-200333020-00005

Connolly, D. A. J., Sayers, S. P., \& Mchugh, M. P. (2003). Treatment and prevention of delayed onset muscle soreness. The Journal of Strength and Conditioning Research, 17(1), 197. https://doi.org/10.1519/1533-4287(2003)017<0197:TAPODO>2.0.CO;2

Dewi, K. L. (2015). Waspadai, 10 efek buruk olahraga berlebihan! Kompas.Com. https://health.kompas.com/read/2015/09/28/090100623/Waspadai.10.Efek.Buruk.Olahraga.Berl 
ebihan.?page=all

Hilbert, J., Sforzo, G., Medicine, T. S.-B. journal of sports, \& 2003, U. (2003). The effects of massage on delayed onset muscle soreness. British Journal of Sports Medicine, 37(1), 72-75. https://doi.org/10.1136/bjsm.37.1.72

Lau, W. Y., Muthalib, M., \& Nosaka, K. (2013). Visual analog scale and pressure pain threshold for delayed onset muscle soreness assessment. Journal of Musculoskeletal Pain, 21(4), 320-326. https://doi.org/10.3109/10582452.2013.848967

Lesmana, H. S., Padli, P., \& Broto, E. P. (2018). Pengaruh recovery aktif dan pasif dalam. JOSSAE : Journal of Sport Science and Education, 2(2), 38. https://doi.org/10.26740/jossae.v2n2.p38-41

Lhaksana, J. (2011). Taktik \& strategi futsal modern. Be Champion.

Perez, J. G., \& Jakeman, P. M. (2010). Citrulline malate enhances athletic anaerobic performance and relieves muscle soreness. Journal of Strength and Conditioning Research, 24(5), 1215-1222. https://doi.org/10.1519/JSC.0b013e3181cb28e0

Proske, U., \& Morgan, D. L. (2001). Muscle damage from eccentric exercise: mechanism, mechanical signs, adaptation and clinical applications. The Journal of Physiology, 537(2), 333-345. https://doi.org/10.1111/j.1469-7793.2001.00333.x

Selkar, S. P., Ramteke, G. J., \& Dongare, A. K. (2009). Effect of eccentric muscle training to reduce severity of delayed onset muscle soreness in athletic subjects. Electronic Journal of General Medicine, 6(4), 213-217. https://doi.org/10.29333/ejgm/82672

Sirait, P. A., Abrori, C., \& Suswati, E. (2015). Pengaruh pemberian jus semangka terhadap kelelahan otot dan delayed onset muscle soreness setelah latihan beban. E-Jurnal Pustaka Kesehatan, 1(1), 132-135. https://jurnal.unej.ac.id/index.php/JPK/article/view/2559

Siregar, V. (2016). Hubungan antara kekuatan otot tungkai dan kelentukan pinggang dengan hasil bowling (melempar bola) di klub Cricket Universitas Negeri Jakarta. Universitas Negeri Jakarta.

Suharjana, S. (2013). Kebugaran jasmani. Jogja Global Media.

Sukadiyanto, S., \& Muluk, D. (2011). Pengantar teori dan metodologi melatih fisik. Lubuk Agung.

Szymanski, D. J. (2001). Recommendations for the avoidance of delayed-onset muscle soreness. Strength and Conditioning Journal, 23(4), 7. https://doi.org/10.1519/00126548-20010800000001

Wardana, L., Irfan, M., \& Ariyanto, A. (2018). Perbedaan aerobik exercise dengan contract relax stretching dan ice massage terhadap penurunan nyeri delayed onset muscle soroness pada hamstring. Universitas' Aisyiyah Yogyakarta. http://digilib2.unisayogya.ac.id/xmlui/handle/123456789/1013

Witvrouw, E., Danneels, L., Asselman, P., D’Have, T., \& Cambier, D. (2003). Muscle flexibility as a risk factor for developing muscle injuries in male professional soccer players. The American Journal of Sports Medicine, 31(1), 41-46. https://doi.org/10.1177/03635465030310011801 